http://dx.doi.org/10.12775/szhf.2016.029

\author{
KRZYSZTOF WAWRZONKOWSKI \\ Uniwersytet MikoŁaja Kopernika, Toruń, Polska \\ KWAWRZONKOWSKI@WP.PL
}

\title{
Rola wyobraźni w Hume’owskiej nauce o naturze ludzkiej. Od teorii poznania do etyki i estetyki
}

Niniejszy artykuł ma na celu przedstawienie roli, jaką w filozofii Davida Hume’a (1711-1776) odgrywają związki kojarzeniowe. Mechanizmy asocjacyjne, będące dla szkockiego filozofa podstawowymi zasadami funkcjonowania wyobraźni, mają zasadnicze znaczenie dla przedstawionej przezeń nauki o naturze ludzkiej. Ich działanie możemy dostrzec we wszelkich dziedzinach ludzkiej aktywności, nie tylko w tworzeniu wiedzy o świecie, ale także w obrębie konstruowanej przezeń etyki i estetyki - w koncepcji bezstronnej oceny ludzkiego zachowania oraz piękna naturalnego i artystycznego.

\section{Rozumienie wyobraźni we wcześniejszych koncepcjach filozoficznych na Wyspach Brytyjskich}

Znaczenia, jakie brytyjscy empiryści przypisywali związkom kojarzeniowym, można upatrywać $\mathrm{w}$ zmianie, która dokonała się w teorii poznania po przyswojeniu przez filozofów brytyjskich filozofii René Descartes’a 
(1596-1650). Dla autora Medytacji o pierwszej filozofii poznanie ugruntowane było w jasności i wyraźności idei intelektu, poznanie zmysłowe zaś - a wraz z nim także obrazy wyobraźni - nie mogąc pretendować do rangi poznania pewnego, uznane zostały jedynie za niejako zbędny dodatek ${ }^{1}$. Jeśli jednak za fundament wiedzy uzna się - jak czyni to John Locke (1632-1704) - doświadczenie, na podstawie którego należy "prostą metodą historyczną"2 wyprowadzić znaczenie wszelkich pojęć. Droga od doznań zmysłowych do pojęć wiedzie poprzez operacje ludzkiego umysłu, w tym także porównywanie, łączenie czy nadawanie nazw ${ }^{3}$. Locke przypisuje je rozumowi, co wiąże się z faktem, że choć w ludzkim poznaniu doświadczenie stanowi dlań punkt wyjścia, a także w pewnym sensie jego cel (ze względu na pomocniczą rolę filozofii względem poznania przyrody czy uzasadnienia twierdzeń religijnych), to analizuje doświadczenie nie tyle „czyste”, ile zapośredniczone językową siatką pojęciową ${ }^{4}$. Problem przejścia pomiędzy materiałem zmysłów a pojęciami empirycznymi zwrócił jego uwagę dopiero później. W rezultacie dopiero w czwartym wydaniu Rozważań z 1700 roku dodał on 33. Rozdział, zatytułowany $O$ kojarzeniu idei. Zawarte tam analizy dalekie jeszcze były od systematycznego ujęcia problemu związków kojarzeniowych wyobraźni, niemniej jednak poza wprowadzeniem do języka filozoficznego samego pojęcia kojarzenia idei (association of ideas), Locke'owi udało się podkreślić pewne istotne cechy powstawania asocjacji i ich rolę w życiu człowieka. Zdaniem autora Rozważań ideom mogą towarzyszyć uczucia przyjemności bądź przykrości. To swoiste sprzęgnięcie operacji wyobraźni oraz wspomnianych doznań miało mieć naturalny charakter, a jego źródła powinniśmy szukać w działaniach dobrotliwego Stwórcy, chcącego ocalić nasze istnienie. Powstałe w ten sposób powiązania pozwalają na funkcjonowanie popędu samozachowawczego, a jednocześnie stanowią podstawę moralności. Przykładem pierwszej funkcji może być skojarzenie idei ognia z uczuciem przykrości, drugiej zaś,

\footnotetext{
${ }^{1}$ Por. J. Kopania, Funkcje poznawcze Descartes'a teorii idei, Dział Wydawnictw Filii UW w Białymstoku, Białystok 1988, s. 95 i n.

2 J. Locke, Rozważania dotyczace rozumu ludzkiego, t. 1, przeł. J. Gałecki, PWN, Warszawa 1955 , s. 24.

3 Tamże, s. 199-202.

${ }^{4}$ Widać to dokładnie zarówno w otwierającej Rozważania deklaracji, w której pojęcie idei Locke definiuje jako „wszystko to, co rozumiemy przez obraz fantazji, pojęcie, gatunek, i wszystko to, czym umysł może się zajmować, gdy myśli” (J. Locke, Rozważania, t. 1, s. 30), jak i w analizie funkcjonowania języka, w której przyjmuje, że znaczeniem słów są właśnie idee (por. tamże, t. 2, s. 10 i n.).
} 
idei uczynności z przyjemnością i aprobatą. Przywołane pary idei i uczuć zostają, zdaniem Locke’a, skojarzone przez nas na drodze doświadczenia i nie są przypadkowe. Filozof zwraca uwagę na potęgę wyobraźni, której siła oddziaływania bierze się z nawyku. Jej wpływ, pozbawiony kierownictwa rozumu, prowadzić może do natręctw i jest dla człowieka zgubny ${ }^{5}$.

Takie połączenie idei zostaje stworzone przez sam umysł i, jak podkreśla Locke, może być ono wynikiem wyboru bądź mieć charakter przypadkowy. Nie zmienia to jednak faktu, że zakłóca ono poprawny bieg rozumowań, ma wpływ na podejmowane decyzje, a nawet ruch ciała. Wszystkie z wymienionych ludzkich czynności stają się nawykowe, co oznacza, że ich przebieg wynika $\mathrm{z}$ utrwalenia doświadczeń, jak w przypadku muzyka, który, gdy tylko usłyszy znajomą melodię, niemal bezwiednie może odegrać ją w wyobraźni. $\mathrm{W}$ ten sam sposób w jego umyśle zjawią się kolejne nuty, układając się w całość słyszaną wielokrotnie wcześniej.

Zarówno ten przykład, jak i te użyte przez Locke’a wyraźnie wskazują, że dostrzegał on pewne cechy związków kojarzeniowych, które dokładnie opisze i wykorzysta w swoich rozważaniach dopiero Hume. Filozof ten, poza stwierdzeniem występowania silnych powiązań między ideami, wielokroć wypaczających obraz naturalnego biegu wydarzeń, filozof dostrzegł również, że mają one znaczny wpływ na aktualne postrzeżenia; nie zachodzą one bowiem przy biernej postawie postrzegającego podmiotu, lecz każdorazowo ujmowane są przez pryzmat minionych doświadczeń. Locke jednak nie rozwija tych wątków, a poczynione uwagi uważa za wartościowe przede wszystkim w dziedzinie wychowania ${ }^{6}$. Aby mogło ono przebiegać w sposób właściwy, należy, jego zdaniem, zapobiec powstawaniu niewłaściwych połączeń między ideami. Choć taki obraz wychowania jest uproszczony i wydaje się dziś dość naiwny, to filozof był jednak świadom istotnej roli, jaką w ludzkim życiu odgrywają związki kojarzeniowe. Ponieważ jednak - podobnie jak u Descartesa - jego zdaniem wiedza ma charakter pewny, wyobraźni przypisana została rola pośrednia, a jej funkcjonowanie, pozbawione korekty ze strony rozumu, właściwe jest umysłowi na wczesnych etapach rozwoju albo w przypadkach jego rozstrojenia.

Jednakże rzucone przez Locke’a ziarno empiryzmu trafiło na urodzajną glebę i - częściowo w sposób przezeń nieprzewidziany - zaczęło przynosić

\footnotetext{
${ }^{5}$ Tamże, t. 1, s. 563-564.

${ }^{6}$ Por. tenże, Myśli o wychowaniu, przeł. F. Wnorowski, Ossolineum, Wrocław-Kraków 1959, s. 42 .
} 
plony. Nawiązujący doń filozofowie kolejnego pokolenia zwrócili uwagę na dwa aspekty funkcjonowania wyobraźni, implicite ukryte w stworzonej przezeń koncepcji. Pierwszy z nich dotyczył roli, jaką odgrywa ona w tworzeniu pojęć empirycznych poprzez wiązanie doświadczeń zmysłowych. Kiedy w 1709 roku George Berkeley (1685-1753) przedstawiał swoje wyjaśnienie procesu widzenia wzrokowego w Próbie stworzenia nowej teorii widzenia, kierował się wskazówkami, które napotkać można w Rozważaniach, tyle tylko, że ich autor sam wykorzystał je jedynie połowicznie. Otóż w przeciwieństwie do przedstawionych wcześniej przez René Descartes'a, Johannesa Keplera czy Issaka Barrowa prób geometrycznego wyjaśnienia zasad postrzegania pierwotnych cech przedmiotów (takich jak wielkość czy położenie), Berkeley przedstawił wykładnię o charakterze psychologicznym, w którym zestawienie heterogenicznego materiału zmysłów wzroku i dotyku dokonywało się w wyobraźni. Oprócz unieważnienia tradycyjnego podziału na pierwotne i wtórne cechy ciał (co w kolejnych dziełach Berkeley wykorzystał jako argument za immaterializmem), podane przezeń wyjaśnienie procesu widzenia pozwalało na określenie funkcjonowania wyobraźni w całości doświadczenia. Zdaniem irlandzkiego filozofa miała ona łączyć dane różnych zmysłów, co pozwalało na stwierdzenie, że wzrok „sugeruje” możliwe doświadczenia cielesne ${ }^{7}$; ostatecznie zaś umożliwia powstanie przedmiotów doświadczenia, będących niejako konstruktem wyobraźni ${ }^{8}$.

$\mathrm{Na}$ inną okoliczność wiążącą się z funkcjonowaniem tej władzy umysłu zwrócił uwagę Shaftesbury (1671-1713), autor poczytnego zbioru Characteristics of Men, Manners, Opinions and Times (1711). Również i on rozwijał pewne intuicje przedstawione przez Locke'a; autor Rozważań starał się bowiem wykazać możliwość sprowadzenia wszystkich pojęć do pojęć empirycznych i wyprowadzenia ich znaczenia na podstawie doświadczenia: także znaczenie pojęć religijnych, np. dobrego, mądrego i wszechmocnego Stwórcy, okazywało się możliwe do zrozumienia o tyle tylko, o ile na podstawie doświadczenia wiadomo, co oznaczają poszczególne przymioty. W swej koncepcji Shaftesbury wyciągnął konsekwencję z tej tezy, wskazując na rolę wyobraźni w powstawaniu pojęć religijnych, które, jak postulował, zależą od wyobrażeń na temat człowieka. Szczególną cechą koncepcji tego angielskie-

${ }^{7}$ G. Berkeley, Próba stworzenia nowej teorii widzenia, [w:] tegoż, Próba stworzenia nowej teorii widzenia $i$ inne eseje filozoficzne, przeł. A. Grzeliński i in., WN UMK, Toruń 2011, s. 69 i n.

${ }^{8}$ Zob. A. Grzeliński, Człowiek i duch nieskończony. Immaterializm George’a Berkeleya, WN UMK, Toruń 2010, s. 60-79. 
go moralisty i estetyka było zwrócenie uwagi na emotywny aspekt doświadczenia - jego entuzjazm dla natury wyrażony w Moralistach ${ }^{9}$ był zarówno wyrazem odartej z dogmatów religijności, jak i przepojonym uczuciem zachwytem nad pięknem. Zarówno zresztą jego estetyka, jak i etyka ufundowane były na możliwości uczuciowej aprobaty, jaką miałoby budzić piękno i dobro ${ }^{10}$. Te dwa aspekty funkcjonowania wyobraźni - jej wskazana przez Berkeleya rola w budowaniu doświadczenia, a także poddane analizie przez Shaftesbury’ego funkcjonowanie ludzkiej afektywności w formułowaniu ocen estetycznych i moralnych - odnajdujemy u Hume’a, przy czym opis funkcjonowania wyobraźni znajduje w jego koncepcji miejsce zasadnicze. Trzeba też dodać, że ogólnie empirystycznie zorientowana filozofia brytyjska niejednokrotnie odwoływała się do asocjacjonizmu, wykazując związki wiedzy z doświadczeniem, odnajdujemy go bowiem zarówno w pracach Thomasa Hobbesa (1588-1679) czy wspomnianego Berkeleya, jak i w późniejszych rozważaniach Davida Hartleya (1705-1757), Thomasa Browna (1778-1822), Jamesa Milla (1773-1836) czy Johna Stuarta Milla (1806-1873). To jednak właśnie Hume był filozofem, który zapoczątkował głębszy namysł nad zjawiskiem łączenia się idei, wprowadzając, najprawdopodobniej niezależnie od ustaleń Arystotelesa ${ }^{11}$, własne, choć częściowo zbieżne z nimi, klasyfikacje zasad kojarzeniowych wyobraźni ${ }^{12}$. Inaczej jednak niż u wcześniejszych bry-

${ }^{9}$ A. A. Shaftesbury, Moraliści, [w:] tenże, List o entuzjazmie. Moraliści, przeł. A. Grzeliński, WN UMK, Toruń 2007, s. 140.

${ }^{10}$ Emotywistyczna koncepcja moralna Shaftesbury'ego najpełniej została przezeń rozwinięta w An Inquiry concerning Virtue and Merit (wczesna wersja: 1699), w których analizuje postawę moralną, odwołując się do harmonii afektów będących pobudkami do działania.

${ }^{11}$ Wprawdzie Locke jako pierwszy użył wyrażenia „kojarzenie idei”, lecz to nie on jako pierwszy wymienił i spróbował sklasyfikować zasady powstawania asocjacji. Ta rola przypadła bowiem już Arystotelesowi. Zastanawiając się nad funkcjonowaniem pamięci i procesów przypominania, stwierdził on, że jej przedmiotem jest przeszłość, te ostatnie zaś możliwe są dzięki śledzeniu związków między utrwalonymi wyobrażeniami, które są rozpatrywane jako obrazy rzeczy. Okazuje się więc, że jeśli chcemy sobie coś przypomnieć, wystarczy kierować się pewnymi zasadami. Stagiryta wskazał na styczność w czasie i przestrzeni, podobieństwo i przeciwieństwo. To one z większą lub mniejszą dokładnością pozwalają nam odtworzyć ciąg minionych wydarzeń. Wprawa w tej sztuce zależy jednak od wielu indywidualnych czynników. Por. Arystoteles, O pamięci i przypominaniu sobie (451 b16-b24), [w:] tenże, Dzieła wszystkie, t. 3, przeł. P. Siwek, PWN, Warszawa 1992, s. 240.

${ }^{12}$ Warto na wstępie podkreślić, że w Badaniach dotyczacych rozumu ludzkiego Hume wymienia trzy zasady kojarzeniowe wyobraźni, są nimi: podobieństwo, styczność w czasie lub przestrzeni oraz przyczyna i skutek. W Traktacie jednak wymienia siedem stosunków filozoficznych: podobieństwo, tożsamość, stosunki czasu i miejsca, stosunek ilości lub liczby, stopnie 
tyjskich filozofów, fundują one całokształt wiedzy na temat świata, a także sferę ludzkich działań, w tym ocenę dzieł artystycznych oraz ludzkich czynów.

\section{Związki kojarzeniowe: ich rola i znaczenie}

Chociaż w swych późniejszych dziełach (Badaniach dotyczacych rozumu ludzkiego (1748) oraz Badaniach dotyczących zasad moralności (1751), a także w esejach) Hume korzysta $\mathrm{z}$ zasadniczo takiego samego zaplecza teoriopoznawczego, najpełniej swoje rozważania teoriopoznawcze przedstawił we wczesnym Traktacie o naturze ludzkiej (1739-1740) ${ }^{13}$. Punktem wyjścia jest dlań analiza treści umysłu, której warunkiem jest zawieszenie sądów egzystencjalnych, dotyczących istnienia przedmiotów wobec nich zewnętrznych - materialnych ciał, substancjalnie pojmowanej duszy czy Boga. Zauważa przy tym, że źródłowym doświadczeniem są impresje, z których dopiero jako ich kopie powstają idee. Obranie za punkt wyjścia analizy treści mentalnych powoduje jednak, że nie można dowieść istnienia świata zewnętrznego, do którego treści te się odnoszą - tym samym Hume idzie śladem Berkeleya i zrywa z Locke’owskim reprezentacjonizmem. Świat rzeczy nie jest już czymś niezależnym w stosunku do poznającego umysłu, jego obraz stanowi konstrukt będący wynikiem procesu poznawczego, w którym zasadniczą rolę - i to Hume uznawał za swe największe odkrycie - odgrywają związki kojarzeniowe. Inaczej zatem niż wcześniej Locke, Hume nie ujmuje operacji wyobraźni jako dodatku do działania rozumu, które bez niego wiodą umysł na manowce, ale - na odwrót - owe operacje wyobraźni, dla opisu

jakości, przeciwieństwo i przyczynowość. Różna ich liczba wynika z faktu, iż w obrębie Traktatu Hume odnosi się do stosunków filozoficznych stanowiących podstawę wiedzy o samych ideach - a więc także do wiedzy matematycznej, podczas gdy w późniejszych Badaniach odnosi się do naturalnych sposobów, w jakie wyobraźnia wiąże idee, co służy mu do wyjaśnienia możliwości sądów o faktach i istnieniu. Por. D. Hume, Badania dotyczące rozumu ludzkiego, przeł. J. Łukasiewicz, K. Twardowski, PWN, Warszawa 1977, s. 25, oraz tenże, Traktat o naturze ludzkiej, przeł. Cz. Znamierowski, Fundacja Aletheia, Warszawa 2005, s. 153.

${ }^{13}$ Chociaż nie przeczy to wadze rozstrzygnięć w pracach późniejszych, na ogół od czasu publikacji fundamentalnej pracy Normana Kempa Smitha The Philosophy of David Hume w 1941 r., badacze skłonni są uznawać całościowy charakter dorobku filozoficznego Hume’a i wskazywać na Traktat jako dzieło o zasadniczym znaczeniu dla jego interpretacji. 
których jako model służyć miał mechanicystyczny opis natury, są niezbędne dla tworzenia obrazu świata.

W przeciwieństwie do impresji, idee są tymi treściami myślenia, wśród których istnieją relacje asocjacyjne; na ich podstawie budowana jest wiedza na temat świata, przede wszystkim związek przyczynowo-skutkowy poddany analizie przez Hume’a, który uznał, że jest on oparty na prostszych związkach: styczności w czasie i przestrzeni oraz podobieństwach ${ }^{14}$. Przekonanie, że za ich pomocą można wyjaśnić nie tylko sposób, w jaki poznawane są procesy przyrodnicze, ale także cały świat ludzki - uczuć, pojęć moralnych oraz estetycznych, towarzyszyło Hume'owi przez całe życie. Jeszcze w swym ostatnim filozoficznym dziele, jakim była Rozprawa o uczuciach (1757) Hume pisał:

Nie roszczę sobie pretensji do tego, że wyczerpałem temat. Dla mego celu wystarczy jednak, jeśli udało mi się ukazać, że w powstawaniu i przepływie uczuć można zauważyć pewien stały mechanizm, który poddaje się równie precyzyjnemu badaniu, jak prawa ruchu, optyki, hydrostatyki czy jakiejkolwiek innej części filozofii naturalnej ${ }^{15}$.

Do impresji zalicza Hume „wszelkie nasze doznania zmysłowe, uczucia i emocje"16. Doświadczenie nie jest jednak bierną percepcją następujących po sobie treści umysłu. Wyobraźnia pozwala wiązać wrażenia i przywoływać z pamięci uczucia skojarzone z określonymi impresjami, przyczyniając się do emocjonalnego dookreślenia percypowanych impresji. Uczucia, jakie jednak wówczas żywimy, nie należą wyłącznie do biernie doznawanych impresji. Odbierane wrażenia zawsze natrafiają bowiem na dyspozycję umysłu, na którą wpływ mają treści ostatnio przezeń percypowane oraz doświadczenia minione. $Z$ powtarzających się obserwacji współwystępowania impresji i uczuć powstaje powiązanie, które z czasem prowadzi do nawykowego zjawiania się idei tych uczuć zaraz po tym, jak w umyśle zagoszczą impresje. To dobrze znane zjawisko rzutowania na aktualne wrażenia minionych doświadczeń nie oddaje jednak jeszcze w pełni roli związków kojarzeniowych w funkcjonowaniu wyobraźni.

\footnotetext{
${ }^{14}$ Szczególnie istotny jest przy tym rozdz. Jak należy sądzić o przyczynach i skutkach: Hume, co prawda, zwraca uwagę na fakt, że związek przyczynowo-skutkowy jest operacją kojarzenia idei przez wyobraźnię, ale jednocześnie uważa, że jest on nieodzowny do zbudowania wiedzy o świecie (por. Traktat, s. 256 i n.).

${ }^{15}$ D. Hume, Rozprawa o uczuciach, przeł. A. Grzeliński, „Filo-Sofija” 2009, nr 1 (8), s. 267.

${ }^{16}$ Tenże, Traktat o naturze ludzkiej, s. 85.
} 
Związki te zasadniczo dotyczą idei, ponieważ o powiązaniach między impresjami nic więcej nie możemy wiedzieć niż to, że występują one jedne po drugich ${ }^{17}$, o czym przekonuje Hume w swej krytyce związku przyczynowo-skutkowego ${ }^{18}$ i rozważaniach poświęconych idei konieczności. Idee te muszą być jednak ideami wyobraźni, a nie jedynie pamięci, cechuje je bowiem żywość ujęcia i świadomość porządku, w jakim zostały ujęte. Idee wyobraźni mogą być ze sobą łączone w dowolny sposób - przestawiane, a nawet swobodnie przekształcane. Kiedy jednak w akcie refleksji spróbujemy ująć treści umysłu, dostrzeżemy pomiędzy nimi pewne związki, które stale się powtarzają. Co ciekawe, Hume’owski model przebiegu doświadczenia nastawiony jest na wyjaśnianie tego, co minione i co dopiero z tej perspektywy może być poddane próbie opisu. To właśnie w naszym minionym doświadczeniu, poddanemu przeglądowi, najłatwiej można dostrzec udział w nim skojarzeń. To, co aktualne, co pierwotne wobec późniejszego opisu, wymyka się bowiem aktom refleksji dokonującego jej podmiotu. Doświadczenie poprzedza jego opis, jest odeń bogatsze, on zaś zawsze jest jakimś jego uproszczeniem.

Powtarzalność współwystępowania określonych idei bądź ich następowania po sobie prowadzi do utrwalenia ich powiązania w wyobraźni. W ten sposób zyskujemy na tyle trwałe skojarzenie, że gdy w umyśle zjawi się jedna idea, to wprowadzi do niego sprzęgniętą z nią drugą ideę. Proces ten w znacznym stopniu rzutuje na nasz sposób odnajdowania się w świecie i konstruowania jego obrazu. Umożliwia przewidywanie następstw zjawiających się idei i odkrywanie tego, co wcześniejsze, na podstawie aktualnych oznak. W każdym takim przypadku wnioskowania oparte są na uogólnieniach poprzednich doświadczeń i dlatego ich wyniki są jedynie prawdopodobne.

Działania takie nie zachodzą jednak za sprawą samej wyobraźni. Do tego celu niezbędny jest rozum pojmowany jako władza pojęć i rozumowania, zwłaszcza moralnego. W przeciwieństwie do rozumowania demonstratywnego, nie odnosi się on jedynie do stosunków między ideami, lecz do faktów $\mathrm{i}$ istnienia. Tym samym, jak wynika z przeprowadzonej przez Hume’a krytyki związku przyczynowo-skutkowego, rozumowanie „moralne” (o faktach i istnieniu) jest jedynie prawdopodobne, stanowiąc uogólnienie wcześniejszych

${ }^{17}$ Dodajmy, że w Traktacie Hume kilkukrotnie wyraża pogląd, zgodnie z którym impresje również podlegają prawom kojarzenia, dotyczy to głównie uczuć, a mówiąc dokładniej, pojawiania się niektórych z nich w umyśle wyłącznie ze względu na podobieństwo do aktualnie doznawanych przeżyć.

${ }^{18}$ Por. D. Hume, Badania dotyczace rozumu ludzkiego, zwł. rozdz. 7: O idei związku koniecznego, cz. II, s. 89-96. 
doświadczeń. O faktach sądzimy na podstawie minionych doświadczeń zmysłowych, ale o istnieniu innych osób, co również jest rodzajem sądów tego rodzaju, nie możemy orzekać inaczej niż na podstawie oddźwięku uczuciowego - niektóre z przeżywanych uczuć (Hume nazywa je uczuciami pośrednimi), takie jak: miłość, pokora czy duma, są zrozumiałe tylko wtedy, gdy założymy istnienie osoby, do której są skierowane ${ }^{19}$.

O ile analiza treści zmysłowych oraz łączących je operacji wyobraźni pozwala w pierwszej księdze Traktatu wyjaśnić, w jaki sposób budowana jest wiedza o przyrodzie, o tyle rekonstrukcja procesu tworzenia obrazu świata ludzkiego - związków pomiędzy ludźmi oraz ocen estetycznych i moralnych - wymaga przedstawienia funkcjonowania ludzkiej uczuciowości; w przedstawionym przez Hume'a opisie ludzkiej natury odpowiada to odrębnej klasie impresji - impresji refleksywnych. Poza podziałem impresji refleksywnych na bezpośrednie (odwołujące się do doświadczenia zmysłowego) i pośrednie (których warunkiem jest funkcjonowanie oddźwięku uczuciowego), ich klasyfikacja uzupełniona jest przez podział tych ostatnich na uczucia łagodne i gwałtowne. „Do pierwszego rodzaju należy poczucie piękna i brzydoty w działaniach - tłumaczy Hume - w utworach artystycznych i w przedmiotach zewnętrznych. Do drugiego rodzaju należą uczucia miłości i nienawiści, smutku i radości, dumy i pokory"20. Wyodrębnienie specyficznej klasy uczuć łagodnych, którym towarzyszą operacje rozumu, jest kluczowe dla wyjaśnienia różnych rodzajów piękna, o których mowa w Traktacie, jak również dla zrozumienia emotywistycznie uwarunkowanej teorii ocen moralnych. Zacznijmy od tej drugiej kwestii.

\section{Związki kojarzeniowe wyobraźni: ich znaczenie w etyce i estetyce}

Fakt, że uczucia łagodne mają za swój przedmiot między innymi cnotę (określaną też jako piękno działań), sprawia, że nasze oceny moralne przybierają w pewnym sensie charakter estetyczny. W Traktacie Hume wprost odwołuje się do koncepcji zmysłu moralnego, rozwiniętej przez Francisa Hut-

${ }_{19}$ Tegoż, Traktat o naturze ludzkiej, s. 357-360, także: A. O. Rorty, 'Pride Produces the Idea of Self': Hume on Moral Agency, „Australasian Journal of Philosophy” 1990, vol. 68, no. 3.

${ }^{20}$ D. Hume, Traktat o naturze ludzkiej, s. 356. 
chesona (1694-1746), który, podobnie jak wcześniej Shaftesbury, postulował istnienie odrębnej, autonomicznej ludzkiej zdolności poznawczej, służącej wydawaniu ocen moralnych i estetycznych. W kilku miejscach filozof nawet zrównuje tę zdolność ze smakiem estetycznym - poczuciem piękna i brzydoty nie tylko „w działaniach”, ale też w przedmiotach natury i dziełach sztuki ${ }^{21}$.

Emotywistycznie uwarunkowana koncepcja ocen moralnych Hume'a zakłada, że ujmowane przez umysł działania są oznaką czyjegoś charakteru, który podlega ocenie, przy czym aprobata bądź dezaprobata mają charakter emocjonalny. Warunkiem takich ocen jest $z$ jednej strony oddźwięk uczuciowy, będący podstawą naszych sądów o istnieniu innych ludzi oraz dający nam pośredni dostęp do ich przeżyć, $z$ drugiej strony zaś, znajomość natury ludzkiej, będącej uogólnieniem indywidualnych doświadczeń jednostki, dotyczących zachowań zarówno własnych, jak i innych. Doświadczenie to pozwala nam tworzyć określone modele ludzkich zachowań, możliwych postaw oraz ich ocen, a także uczy nas tego, jak uczucia potrafią wiązać się ze sobą i przechodzić jedno w drugie. Każde zaobserwowane zachowanie stanowi oznakę wewnętrznych przyczyn, do których jednak nie mamy bezpośredniego dostępu. Musimy więc dopowiedzieć je sobie na podstawie znajomości ludzkiej natury, a ta nie będzie dla nas zrozumiała, dopóki nie odkryjemy roli związków kojarzeniowych wyobraźni. Oczywiście cała procedura nie rozgrywa się jedynie w sferze wyobraźni, ale uzyskuje wsparcie ze strony rozumu (understanding); swoją rolę może odegrać tu również język. Hume bardzo mocno podkreśla jego wpływ na nasze rozumienie świata, na pejoratywne i pozytywne nacechowanie określonych pojęć, z których mocy skojarzeniowej nie zawsze zdajemy sobie sprawę. Świat, w który wrastamy, staje się do pewnego stopnia naszą naturą, wyznacza nam swoisty horyzont, na tle którego wszystko się rozgrywa. Już młody obserwator życia społecznego dostrzega, że pewne zawody, zachowania, cechy charakteru czy przymioty umysłu cieszą się powszechną aprobatą, inne zaś wzbudzają niechęć i politowanie. Dostrzeżenie tej płaszczyzny ocen wiąże się jednak z rozpoznaniem użyteczności czy też przydatności określonych zachowań dla społeczności oraz nas samych. Pro-

\footnotetext{
${ }^{21}$ Shaftesbury posługuje się przy tym zamiennie pojęciem „zmysłu tego, co słuszne i niesłuszne (the sense of right and wrong), natomiast piszący na początku lat 40. XX w. Hutcheson uznaje, że pojęcie to jest już powszechnie akceptowane przez filozofów; por. A. A. Shaftesbury, An Inquiry Concerning Virtue, or Merit (1699), [w:] Characteristics of Men, Manners, Opinions, and Times, vol. 2, ed. D. den Uyl, Indianapolis 2001, s. 24, a także: F. Hutcheson, An Essay on the Nature and Conduct of the Passions and Affections, with Illustrations on the Moral Sense (1742), ed. A. Garrett, Liberty Fund, Indianapolis 2002, s. 7.
} 
ces ten nie zachodzi jednak na gruncie samych uczuć, konieczna jest bowiem korektura uczuć ze strony rozumu. Dzięki niej oceny moralne, o których nie można przecież orzekać w kategoriach prawdziwości bądź fałszywości, mogą zostać rozpoznane jako właściwe bądź nie. W drugim przypadku, rozum może podpowiedzieć, jak zmienić je na poprawne, a w zasadzie: pożądane bądź akceptowane przez społeczność, w której funkcjonujemy. Jednocześnie zaś wskazuje on nam drogę do tego celu, jakim jest obranie pewnego stałego, obiektywnego punktu widzenia, przypisanego hipotetycznemu bezstronnemu obserwatorowi, dzięki któremu możemy abstrahować od własnej sytuacji życiowej. W ten sposób, zapewniając swym ocenom bezinteresowność, sprawiamy, że stają się właściwe ${ }^{22}$. Można by zapytać, czy wpływ czynnika środowiskowego, społecznych uwarunkowań, nie będzie przypadkiem odgrywał zbyt dużej roli w determinowaniu naszych ocen moralnych. Na gruncie filozofii Hume’a należałoby odpowiedzieć, że z pewnością dużo większy wpływ na nie mają czynniki stałe, czyli w tym przypadku pewne naturalne dla człowieka uczuciowe reakcje na ludzkie zachowania. Czynniki zewnętrzne w postaci warunków społecznych dostarczają treści (a w zasadzie sposób ich przejawiania się w ludzkim świecie), na których operuje wyobraźnia i rozum, a także kształtują nas pod względem pewnych zachowań społecznych. Oddźwięk uczuciowy umożliwia natomiast współdoznawanie cudzych cierpień i radości, stając się podstawą sądów o cnotach naturalnych - typowych dla ogółu ludzi, i sztucznych - zmiennych i zależnych od sytuacji historycznej i politycznej ${ }^{23}$. Podobną argumentację odnajdujemy w drugiej dziedzinie filozofii praktycznej: estetyce.

\footnotetext{
${ }^{22}$ Zob. M. Rutkowski, Teoria „bezstronnego obserwatora” w etyce Dawida Hume’a, „Studia Filozoficzne" 1989, nr 5.

${ }^{23}$ Por. następującą uwagę Hume’a: „Tak więc okazuje się, że oddźwięk uczuciowy jest bardzo potężnym czynnikiem w naturze ludzkiej, że ma wielki wpływ na nasze poczucie piękna i że wytwarza nasze poczucie moralne we wszelkich cnotach sztucznych. Stąd możemy z góry przypuszczać, że daje on początek wielu innym cnotom; i że cechy człowieka zyskują naszą aprobatę ze względu na to, iż prowadzą do czegoś, co jest dobre dla ludzkości [...]. Jedyna różnica między cnotami naturalnymi a sprawiedliwością polega na tym, że korzyść, która wynika $\mathrm{z}$ tych pierwszych, powstaje w każdym poszczególnym działaniu i jest przedmiotem jakiegoś naturalnego uczucia, gdy tymczasem poszczególny akt sprawiedliwości, rozważany sam w sobie, może często być sprzeczny z dobrem publicznym; i tylko współdziałanie ludzi w ogólnym planie czy systemie działań jest korzystne”, D. Hume, Traktat o naturze ludzkiej, s. 657-658). Najpełniejszą analizę koncepcji cnót sztucznych oraz teorii politycznej w polskiej literaturze przedmiotu przedstawił Tomasz Tulejski w: Konserwatyzm bez Boga. Dawida
} 
W Hume'owskich rozważaniach estetycznych możemy wyodrębnić kilka płaszczyzn, na których przejawia się wpływ związków kojarzeniowych. Przede wszystkim musimy zauważyć, że w obszarze szeroko pojmowanego doświadczenia estetycznego niezwykle istotna jest wiedza o świecie, jego budowie i rządzących nim prawach, o przedmiotach przyrody i ich różnorodności, wreszcie o ludziach, ich wyglądzie, zachowaniach i w ogóle o wszelkich elementach ludzkiej natury. Cała ta wiedza służy bowiem do skonstruowania takiego obrazu świata, w jakim ważną rolę odgrywają związki kojarzeniowe, bez znajomości których ani artysta nie mógłby stworzyć niczego, co poruszyłoby umysł odbiorcy, ani ten ostatni przeżyć w doświadczeniu estetycznym tego, co zaplanował dlań pierwszy ${ }^{24}$. Można powiedzieć nawet więcej. Żaden człowiek nie mógłby poprawnie funkcjonować w świecie bez zdobycia tego typu wiedzy, nie mógłby bowiem ani niczego przewidzieć, ani niczego zrozumieć.

$\mathrm{Z}$ drugiej strony wiedza zdobyta $\mathrm{w}$ doświadczeniu przyczynia się do bogactwa materiału porównawczego dostępnego wyobraźni, który odgrywa znaczącą rolę przy wydawaniu sądów smaku estetycznego. Wrażliwość wyobraźni, czyli jej zdolność do uchwycenia najdrobniejszych elementów składowych przedmiotów przyrody, rzeczy codziennego użytku czy dzieł sztuki, pozwala przy tym na łatwiejsze wychwytywanie powiązań miedzy ideami. Dzięki śledzeniu tych powiązań wyobraźnia szybciej odnajduje związki zachodzące pomiędzy poszczególnymi elementami składowymi przedmiotów smaku. Możliwość ich śledzenia i stosunkowo łatwe, ze względu na wrażliwość wyobraźni, poddawanie się przez smak oddziaływaniom przedmiotów, skutkuje zmianami dyspozycji umysłu. Z każdą taką zmianą jego nastawienia kolejne idee mogą być ujmowane w inny sposób. Przykładowo podziw,

Huméa wizja społeczeństwa, państwa i prawa, Fijorr Publishing, Chicago-Warszawa 2009 (por. zwł. s. 125-152).

${ }^{24}$ Por. na ten temat następującą uwagę Hume’a: „We wszystkich utworach literackich potrzeba zatem, by pisarz miał pewien plan i cel; a chociaż od planu tego może odciągnąć go poryw myśli, jak w odzie, lub nagła zmiana wątku, jak w liście czy eseju, to jednak przynajmniej w początkach pisania, jeśli już nie w pracy nad całością, musi przyświecać mu pewna intencja. Dzieło bez planu wyglądałoby raczej na bredzenie wariata niż efekt poważnych wysiłków talentu i wiedzy. Ponieważ reguła ta nie dopuszcza żadnego wyjątku, przeto wynika stąd, że w utworach narracyjnych zdarzenia i czyny, które nam autor przedstawia, muszą wiązać się ze sobą za pomocą jakiegoś ogniwa czy łącznika. Muszą w naszej wyobraźni pozostawać ze sobą w pewnych stosunkach i tworzyć pewnego rodzaju jedność, która umieszczałaby je w jednej perspektywie czy płaszczyźnie i wyrażała ów temat czy cel, o którym myślał autor, gdy przystępował do dzieła", D. Hume, Badania dotyczące rozumu ludzkiego, s. 26, przyp. 6). 
jaki żywimy w stosunku do krajobrazu, wzrasta z każdym nowym elementem w nim uchwyconym, o ile ten do niego lub do samej dyspozycji umysłu pasuje. Widok skał górujących nad jeziorem, rozlanym pośród kwiecistych łąk, jest przykładem doświadczenia estetycznego, w którym wyobraźnia wraz z kolejnymi ujmowanymi impresjami wypełnia się ideami uczuć, z którymi impresje te kojarzy. Nie jest więc tak, że tylko aktualnie ujmowane kształty czy też proporcja, harmonia i symetria wzbudzają przyjemność wyobraźni, ale również dołączają się do nich uczucia (idee refleksywne) z nimi skojarzone, a także najróżniejsze idee, które za pomocą związków kojarzeniowych mogą się z nimi wiązać.

Wróćmy do podziału impresji refleksywnych na łagodne i gwałtowne. Przypomnijmy, że do pierwszego rodzaju należy, między innymi, „poczucie piękna i brzydoty w działaniach, w utworach artystycznych i w przedmiotach zewnętrznych. Do drugiego rodzaju należą uczucia miłości i nienawiści, smutku i radości, dumy i pokory" 25 . Przeprowadzony podział uczuć umożliwia Hume'owi mówienie o pięknie na dwa sposoby. Pierwszy z nich to opis percepcji zmysłowej określonych jakości przedmiotów, głównie ich kształtów, bądź co bądź, to do nich w zasadzie Hume sprowadza piękno tego rodzaju ${ }^{26}$. W tym przypadku nasze przeżycia uczuć przyjemnych, wsparte, rzecz jasna, uczuciem przeświadczenia dotyczącym istnienia przedmiotu oceny estetycznej, nie dają się w żaden sposób komunikować. Doznawana przyjemność jest być może - jak powiada Hume - związana z przedmiotem, którego percepcji towarzyszy, jednak nie możemy być tego pewni. Związek ten miałby wówczas charakter naturalny, choć jeśli piękno dane jest przez uczucia to - jak znowu zauważa Hume - jego doświadczenie miałoby charakter jedynie indywidualny.

Drugi sposób to opis piękna, które zasadza się na uczuciach gwałtownych, a dokładnie na uczuciu dumy. Jest to piękno, które moglibyśmy określić jako społeczne czy intersubiektywne. Jego doświadczenie możliwe jest dzięki oddźwiękowi czuciowemu, gdyż do czerpania z niego radości niezbędni są inni ludzie. Dlatego też duma będąca uczuciem gwałtownym jest jednocześnie uczuciem pośrednim, czyli wymagającym do swego zaistnienia przynajmniej

\footnotetext{
${ }_{25}$ Tenże, Traktat o naturze ludzkiej, s. 356.
}

${ }^{26}$ Por. następującą uwagę Hume’a: „Z niezliczonych przykładów tego rodzaju oraz ze zrozumienia tego, iż piękna, podobnie jak dowcipu, nie można zdefiniować, lecz tylko można je rozpoznać przez smak czy doznanie zmysłowe, możemy wyprowadzić wniosek, że piękno nie jest niczym innym niż kształtem, który daje przyjemność, brzydota zaś takim powiązaniem części, które daje przykrość”, D. Hume, Traktat o naturze ludzkiej, s. 379). 
dwóch osób. Jeśli teraz mówimy o komunikowalności tego, że coś jest piękne, to potrzebujemy do tegooperacji rozumu, który podciąga konkretne idee pod pojęcia. Zmuszeni jesteśmy wówczas odwołać się do pojęcia użyteczności. Okazuje się bowiem, że jest to pojęcie najlepiej współgrające z ludzką potrzebą doznawania przyjemności związanych z uczuciem dumy. Jak wiemy, przedmiotem dumy jest zawsze nasze ja, dlatego też rzecz, która ma ją wywołać, musi być $\mathrm{z}$ nami w jakiś sposób związana ${ }^{27}$. Trudno być dumnym z osiągnięć kogoś obcego. Jeśli natomiast mamy szybkiego konia, ustawny dom czy zwrotną łódź, to nie dość, że przedmioty te cieszą oko ze względu na swe walory estetyczne, że nawet należą do mnie, to jeszcze ważniejsze jest to, że inni to widzą, że udzielają się im uczucia właściciela:

Człowiek - argumentuje Hume - który nam pokazuje jakiś dom czy budynek, stara się szczególnie między innymi o to, ażeby zwrócić uwagę na wygody mieszkań, na korzystne ich położenie, na to, że niewiele miejsca zajmują schody, przedpokoje i korytarze. I istotnie jest oczywiste, że znaczna część piękna polega właśnie na tych szczegółach. Stwierdzenie, że rzecz jakaś jest wygodna, daje przyjemność, bowiem wygoda jest pięknem. Lecz w jaki sposób daje ona przyjemność? Jest rzeczą pewną, że nasz własny interes nie wchodzi tu w najmniejszej mierze w rachubę; że zaś jest to piękno, by tak rzec, interesu, nie zaś formy, to musi ono nam dawać zadowolenie jedynie przez to, iż się nam udziela uczucie właściciela mieszkania drogą oddźwięku uczuciowego. Wchodzimy w jego zainteresowaną postawę mocą wyobraźni i doznajemy tego samego zadowolenia, jakie różne rzeczy w naturalny sposób w nim wywołują. Ta obserwacja rozciąga się na stoły, krzesła, sekretery, kominy, powozy, siodła, pługi i na wszelkie dzieła sztuki: jest regułą powszechną, że ich piękno polega głównie na ich użyteczności i przydatności do tego celu, do którego są przeznaczone; lecz jest to pożytek tylko dla właściciela, i jedynie oddźwięk uczuciowy może wzbudzić zainteresowanie $\mathrm{w}$ widzu ${ }^{28}$.

A zatem dopiero wtedy, kiedy można niejako przejrzeć się w czyichś oczach, kiedy widać w nich błysk zazdrości, dopiero wówczas odczuwa się dumę, dopiero wówczas można cieszyć się przedmiotami uchodzącymi w towarzystwie za piękne. W XVIII wieku były to rzeczy najróżniejsze, od budowli architektonicznych po najdrobniejsze elementy wystroju wnętrz. Istotne jednak było to, że ze względu na chęć komunikowania się na ich temat

\footnotetext{
27 Tenże, Traktat o naturze ludzkiej, s. 370-374.

${ }^{28}$ Tamże, s. 440.
} 
$\mathrm{z}$ innymi i dyskutowania o nich, niezbędne było podciągnięcie konkretnych idei pod pojęcie użyteczności. W przeciwnym wypadku nie było możliwości dyskutowania na temat piękna. Co równie ważne, dla tego rodzaju piękna związki kojarzeniowe odgrywały istotną rolę w konstruowaniu obrazu życia społecznego, także w poprawnym rozumowaniu na temat piękna jako użyteczności oraz zdolności podpatrywania zachowań wyższych warstw społecznych w dziedzinie wystroju wnętrz. Tu, jak w wielu innych przypadkach, przykład szedł z góry, jednak naśladowcy nie zawsze udawało się uzyskać podpatrzony efekt.

Oba wymienione powyżej rodzaje piękna, przedstawione w Traktacie, nie odnoszą się jednak do dzieł sztuk pięknych, opinie na temat tych ostatnich opierają się bowiem na nieco innych zasadach. Ale to dopiero wraz z wyjaśnieniem możliwości wydawania sądów na ich temat koncepcja estetyczna Hume’a zyskała wartość. W Traktacie interesowała go przecież natura ludzka, a nie zachwyt człowieka nad dziełami sztuki. Niemniej rozważania zawarte w późniejszym od Traktatu o siedemnaście lat Sprawdzianie smaku utrzymują w mocy wszystkie teoriopoznawcze rozstrzygnięcia Hume' owskiej filozofii.

Doświadczenie piękna pojmowane jest tu jako rodzaj uczucia, na które wpływ ma jakość percypowanego przedmiotu. Skoro dzieła sztuki mają swoich twórców, to należy zwrócić uwagę na ich działania, zamierzenia i to, co $\mathrm{z}$ nich $\mathrm{w}$ dziełach zostaje. Tym samym Hume wprowadza do rozważań estetycznych kategorię celowości, pojmowaną przezeń jako celowe działania artysty, którego możemy za nie rozliczyć. Twórca powinien zatem znać mechanizmy rządzące wyobraźnią i w odpowiedni sposób poddawać jej treści, na których będzie mogła ona dalej operować. W eseju Sceptyk Hume pisze tak:

Przy rozumowaniu umysł nie robi nic innego jak tylko to, że dokonywa przeglądu przedmiotów, jakimi się zdają być w rzeczywistości, nic do nich nie dodając ani nie odejmując. [...] Zdaje się przeto, że ta czynność umysłu znajduje zawsze w naturze rzeczy realny, nam często nieznany, sprawdzian, i że prawda i fałsz nie zmieniają się zależnie od różnej postawy człowieka. [...] Natomiast inaczej niż z prawdą i fałszem jest $\mathrm{z}$ własnościami takimi, jak piękny i brzydki, pożądany i wstrętny. Tu umysł nie ogranicza się do rozpatrywania przedmiotów, jakimi są same przez się. Na skutek ich rozpatrywania przeżywa również zachwyt i przykrość, uznanie i potępienie, przeżycia te zaś skłaniają go do nadawania przedmiotom epitetów piękny i brzydki, pożądany i wstrętny. Otóż jest oczywiste, że przeżycia te muszą zależeć od szczególnego mechanizmu czy struktury umysłu, które poszczególnym formom pozwalają nań działać w swo- 
isty sposób i wytwarzają sympatię czy też zgodność między umysłem a jego przedmiotami ${ }^{29}$.

Twórca musi być znawcą ludzkiej natury i jako bystry obserwator powinien nauczyć się doprowadzać do wspomnianej przez Hume’a zgodności między umysłem a jego przedmiotami. Owa zgodność z jednej strony odnosi się do pewnych naturalnych powiązań uczuć z jakościami zmysłowymi, które miałyby one wzbudzać, z drugiej zaś, za sprawą doświadczenia umożliwionego dzięki procesom kojarzenia, możemy ustalić nowe powiązania, a więc i nowe sposoby wzbudzania uczuć. W obu przypadkach artysta, który działa, opierając się na znajomości ludzkiej natury, może więc w sposób celowy wywoływać określone stany emocjonalne. Nie dokona tego jednak bez wykorzystania związków kojarzeniowych. Wiedząc zatem, jak pewna idea wprowadza do umysłu kolejną, a także jak wpływa ona na dyspozycję odbiorcy, może on odpowiednio „skonstruować” dzieło sztuki. Piszę „skonstruować”, gdyż w takim ujęciu zagadnienia artysta faktycznie nie zdaje się jedynie na własne uczucia, przypływ entuzjazmu czy natchnienie, lecz musi uwzględnić wiele czynników, bez których zamierzony efekt w ogóle może nie zostać wywołany. Nie biorąc pod uwagę odbiorców swego dzieła, ich upodobań, wyrobienia kulturalnego, nastrojów, wiedzy, a nawet uprzedzeń, z pewnością chybi celu. Pamiętając o tym wszystkim, zwiększa swe szanse na powodzenie, na właściwy dobór środków do realizacji swych idei estetycznych. Według Hume’a ostatecznie tylko z tego możemy rozliczyć artystę.

Aby lepiej zrozumieć rolę związków kojarzeniowych w doświadczeniu estetycznym, musimy przyjrzeć się również temu, kto stoi naprzeciw przedstawianego dzieła. Dopiero bowiem omawiając zagadnienia kształcenia smaku i kryterium prawdziwości jego sądów, zyskamy pełen obraz interesującej nas problematyki.

Zdaniem Hume'a:

piękno nie jest własnością przedmiotów samych przez się; istnieje jedynie w umyśle, który je ogląda, a każdy umysł dostrzega inne piękno. Niektórzy nawet widzą brzydotę tam, gdzie inni widzą piękno. Każdy powinien też przyjmować swe własne odczucie, nie usiłując normować także cudzych. Szukanie prawdziwego piękna czy prawdziwej brzydoty jest równie bezowocne, jak chęć ustalenia, co jest naprawdę słodkie, a co gorzkie. W zależności od naszych na-

${ }^{29}$ Tenże, Sceptyk, [w:] Eseje z dziedziny moralności i literatury, przeł. T. Tatarkiewiczowa, PWN, Warszawa 1955, s. 124. 
rządów ta sama rzecz może być zarówno słodka, jak i gorzka, słusznie więc przysłowie mówi, że bezcelowy jest spór w kwestiach smaku. Jest rzeczą słuszną, a nawet potrzebną rozciągnąć ten pewnik na smak umysłowy, tak jak na fizyczny ${ }^{30}$.

Przy takim pojmowaniu piękna Hume nie jest w stanie wskazać na konkretne cechy przedmiotów, które miałyby być odpowiedzialne za wywołanie właściwego dlań uczucia. Nadal jednak obowiązuje warunek, zgodnie z którym wartościowe sądy smaku estetycznego może wydawać jedynie osoba o zdrowych zmysłach. Jakiekolwiek bowiem zaburzenie ich pracy uniemożliwia poprawne, $\mathrm{w}$ sensie - spełniające podstawowe wymagania poznawcze, obcowanie z dziełem sztuki. To jednak nie zmysły stanowią o poprawności funkcjonowania smaku estetycznego, a właśnie wyobraźnia, która jest odpowiedzialna za wartość samego doświadczenia estetycznego i wydanych na jego podstawie sądów smaku. Od wrażliwości władzy wyobrażeń zależy szybkie i łatwe przebieganie między ideami, zestawianie ich ze sobą, śledzenie nowych możliwych powiązań i odniesień do innych dzieł. Ta ostatnia praktyka ma dla Hume'a wielkie znaczenie. Uważa on bowiem, że nie ma ważniejszego ćwiczenia dla wyobraźni niż obcowanie z dziełami najrozmaitszych sztuk pięknych i wprawianie się w wydawaniu sądów na ich temat. Gromadzimy w ten sposób zmysłowy materiał porównawczy, a co ważniejsze, wytwarzamy całe serie nowych powiązań między ideami. Dzięki temu nasz smak może wydawać pełnowartościowe sądy estetyczne. Problem jednak tkwi w tym, że nawet największa wrażliwość wyobraźni i subtelność smaku nie sprawią, iż przekroczymy w ten sposób indywidualne uwarunkowania owych sądów. Dlatego też Hume proponuje wprowadzenie zewnętrznego prawidła rozstrzygającego, ,jakie z tych odczuć należy pochwalać, a jakie potępiać"31.

W tym miejscu dochodzi do przekroczenia płaszczyzny uczuć, na której zazwyczaj rozgrywa się doświadczenie estetyczne i pojawia się ich korektura ze strony rozumu. Hume niechętnie to robi, gdyż zdaje sobie sprawę z tego, że w jakiś intuicyjny sposób większość z nas zgadza się co do ocen większości przedmiotów. Brak mu jednak odpowiednich narzędzi filozoficznych, by ostatecznie móc dowieść swych racji i wyjaśnić zajęte stanowisko. Dlatego też wzorem rozwiązania w zakresie etyki, gdzie przyjmuje idealny bezstron-

\footnotetext{
${ }^{30}$ Tenże, Sprawdzian smaku, [w:] Eseje z dziedziny moralności i literatury, s. 194.

${ }^{31}$ Tamże, s. 193.
} 
ny punkt widzenia, proponuje, aby również w dziedzinie oceny dzieł sztuki wprowadzić takie kryterium poprawności ocen. Owym kryterium ma tu być zgodny sąd sprawiedliwych krytyków. Uczucia, które zawsze są poprawne, gdyż odwołują się jedynie do siebie, zostają nagle skonfrontowane z zewnętrznym sprawdzianem smaku estetycznego, przybierającym postać wielu indywidulanych, choć zgodnych, sądów ekspertów. Dopóki nasz sąd nie daje się uzgodnić $\mathrm{z}$ ich sądem, opartym na bogatym doświadczeniu zawodowym każdego z nich, na wrażliwości ich wyobraźni, osobistych zdolnościach artystycznych, wiedzy dotyczącej powstania dzieła, a nawet szkoły, do jakiej ono należy, oraz uzupełniającego całość tła historycznego epoki, w której przyszło autorowi tworzyć, dopóty musimy kształcić nasz smak zgodnie z ich wytycznymi. Oznacza to, że obcując z każdym kolejnym dziełem, którego ekspercką ocenę znamy, uwrażliwiamy naszą wyobraźnię i kształcimy smak we właściwym kierunku. To z kolei oznacza, że we władzy wyobrażeń powstają nowe związki pomiędzy impresjami i ideami, że zjawiają się nowe towarzyszące im uczucia. Im większy zaś będzie jej materiał porównawczy, czyli z im większą liczbą dzieł sztuki będziemy obcować, tym więcej idei zdobędziemy i tym łatwiej i szybciej wyobraźnia je wyśledzi. Pozwoli to wówczas na dojście do głosu kolejnych uczuć, na fali których następne impresje spotęgują nasze doznania płynące z doświadczenia piękna.

\section{Raz jeszcze o wyobraźni}

Z przedstawionych analiz wyłania się obraz wyobraźni jako najważniejszej zdolności poznawczej. Z jednej bowiem strony na gruncie filozofii Hume’a trudno mówić o przedmiotach zmysłów inaczej jak o konstruktach wyobraźni, o realności których przekonuje przeświadczenie. Z drugiej strony natomiast, rozum zostaje sprowadzony przez niego do roli zdolności podciągającej konkretne impresje pod pojęcia oraz do dwóch rodzajów rozumowań: demonstratywnego i moralnego. Zdolność wyobrażania pełni więc w jego systemie filozoficznym funkcję centralnej władzy poznawczej, a jej mechanizmy decydują o ostatecznym obrazie świata, jaki wyłania się z wysiłku zrozumienia przez człowieka jego doświadczenia.

Idąc dalej tym tropem, należy zauważyć, że wyobraźnia nie tylko jest zdolnością odnoszącą się do aktualnych treści jako istniejących „na zewnątrz”, ale pozwala również na przewidywanie tego, co przyszłe, jak i odkrywanie tego, 
co przeszłe ${ }^{32}$. W obu ostatnich przypadkach dokonuje tego poprzez projekcje indywidualnych doświadczeń każdego człowieka. Dla Hume’a odkrycie związków kojarzeniowych, a dokładniej ich roli, zarówno w konstruowaniu doświadczenia, jak i tłumaczeniu znaczeń najróżniejszych serii impresji było znaczącym krokiem w kierunku zrozumienia ludzkiej natury. W jego mniemaniu udało się wreszcie odkryć prawa rządzące wyobraźnią, a tym samym zrozumieć ludzkie odnajdywanie się w świecie, rozumiane tu jako porządkowanie materiału postrzeżeniowego według zasad kojarzeniowych, oraz antycypacja przyszłych doświadczeń i uzupełnienie dostępnych umysłowi treści.

$\mathrm{Z}$ analiz Hume’a poświęconych wyobraźni wynika, że praktyczny wymiar zastosowania jej związków kojarzeniowych w zasadzie nigdzie się nie kończy. Dopóki bowiem pozostajemy w obrębie zmysłowości, to jest dopóki operujemy na obrazach, rozumianych jako wszelkie dane postrzeżeniowe, zmuszeni jesteśmy do zestawiania ich ze sobą i łączenia zgodnie ze wskazanymi przez niego rodzajami asocjacji. Dodatkowo, jeśli zgodzić się z autorem Traktatu, że owym związkom podlegają również uczucia, to okaże się, że tak zarysowana koncepcja zdolności wyobrażania odpowiada za całość ludzkiego doświadczenia. Jak jednak należy rozumieć takie wnioski?

$\mathrm{Na}$ to pytanie można odpowiedzieć, zaczynając od przedstawienia modelu przebiegu procesów poznawczych, jaki zaproponował Hume. Rozmaitość ludzkich doświadczeń powoduje, że każdy człowiek na podstawie innego materiału postrzeżeniowego konstruuje własne wyobrażenie tego, co nazywamy światem. $Z$ powtarzających się serii następujących po sobie impresji, na drodze indukcji wyprowadzamy dotyczące go reguły i prawa. Rozumowania moralne, jak pamiętamy, są jedynie prawdopodobne, a więc i nasza wiedza na temat funkcjonowania naszego skonstruowanego świata musi być prawdopodobna. Nie mając pewności, co do koniecznych reguł własnych zachowań, tym bardziej nie możemy jej mieć w odniesieniu do innych ludzi. Ich charaktery są dla nas swoistą kumulacją postrzeżeń, które nas z nimi łączą, a więc sprowadzają się do pewnych doświadczeń, głównie zmysłowych, którym towarzyszą określone uczucia, przedsądy, wyobrażenia. Tak powstaje wiedza na temat innych osób, jednak już motywy ich postępowania są nam znane wyłącznie dzięki analogii do naszych własnych zachowań i motywacji.

${ }^{32}$ W koncepcji Hume'a ten wątek wybija się zresztą, jak mi się wydaje, na pierwszy plan. Związki kojarzeniowe wyobraźni dużo łatwiej dają się bowiem wyzyskać do opisywania przeszłości, wybiegania myślą w przyszłość lub, po prostu, do tworzenia fikcji literackich czy, szerzej, w ogóle do twórczości artystycznej. 
A jednak nie przeszkadza nam to w lubieniu kogoś, szanowaniu czy stawianiu za wzór. Dzieje się tak dlatego, że nawykowy sposób łączenia idei pozwala nam tworzyć wiele typów idealnych, jeśli można tak powiedzieć, w które poszczególne osoby i ich charaktery, lepiej lub gorzej się wpisują. Związki kojarzeniowe umożliwiają nam rozumienie tego, co akurat zachodzi w polu naszej świadomości w świetle minionych doświadczeń i przez pryzmat skonstruowanych na ich bazie ogólnych wzorów zachowann ${ }^{33}$. Z takiego punktu widzenia świat jawi się jako przytrafiające się nam wrażenia, my zaś pozostajemy sami w jego centrum. Ta sytuacja ulega jednak zmianie wraz z „rozwojem” tego wyobrażonego, choć jedynego w tej perspektywie, świata.

Im bystrzejszy bowiem obserwator, tym bardziej szczegółowa wiedza na temat natury ludzkiej, a tym samym, większa liczba ludzkich typów i wzorów zachowań. Bogactwo tak zakreślonej wiedzy życiowej daje większą możliwość zrozumienia samego siebie, a więc i konkretnej sytuacji, w jakiej się znajdujemy. Umożliwia to zdystansowanie się do niej, a przynajmniej ułatwia stworzenie modelu idealnego obserwatora tej sytuacji i jego względem niej zachowań. Ta zdolność abstrahowania od własnego punktu widzenia, do przyjęcia odmiennej postawy, prowadzi do zdroworozsądkowego spojrzenia na konkretne zdarzenia i do przekroczenia osobistej perspektywy na rzecz bezstronnej postawy, cechującej na przykład obserwatora i krytyka. Idealny obserwator pozostaje jednak jedynie pewnym konstruktem wyobraźni. Doświadczenie uczy nas bowiem, jeśli tylko dobrze mu się przyjrzeć, jakie cechy osobowe są przydatne w społeczności, a dokładniej, jakie cechy winien mieć każdy reprezentant swojej profesji. Zarówno uczciwość piekarza, jak i rejenta, podobnie jak sprawiedliwość ławnika i rodzica, zawsze będą w cenie. Pomyślność życiowa, jaką zapewniają tego typu cnoty społeczne, sprawia, że są one pożądane i wysoko stawiane w hierarchii przymiotów osobowych. Im szybciej zatem dojdziemy do tego, które z nich cenić, a które ganić, oraz kto powinien je wcielać w życie, tym szybciej zrozumiemy, jak skonstruować idealny model stosunków międzyludzkich, a w nim postaci idealnego obserwatora i sprawiedliwego krytyka. Ta dwójka bowiem, jak to już widzieliśmy, stanowi dla Hume'a ważne elementy jego etyki i estetyki.

Zdolność ustalenia tego typu idealnych wzorów zachowań, czy też zbiorów konkretnych przymiotów osobowych, pozwala dokonywać właściwych ocen. $\mathrm{W}$ tym przypadku oznacza to nie tyle zrezygnowanie $\mathrm{z}$ uczuć, ile dodanie do nich odrobiny światła rozumu. To zaś możliwe jest dzięki wyśledzeniu

${ }^{33}$ Tego typu kategoryzacje dotyczą oczywiście wszelkich przejawów ludzkiego życia. 
funkcjonowania związków kojarzeniowych. Jakże bowiem inaczej wczuć się w rolę takich obserwatorów i krytyków? Jakże inaczej skonstruować taki model świata, w którym rezygnujemy z osobistej perspektywy wszelkich ocen? Bez jej przekroczenia skazani jesteśmy na to, co aktualne, na to, co nam się przedstawia, i pozbawieni wizji tego, jak być powinno.

\section{Bibliografia}

Anderson R. F., Hume's Account of Knowledge of External Objects, „Journal of the History of Philosophy" 1975, vol. 13, no. 4.

Árdal P., Passion and Value in Hume's Treatise, Edinburgh University Press, Edinburgh 1966.

Arystoteles, O pamięci i przypominaniu sobie, [w:] tenże, Dzieła wszystkie, t. 3, przeł. P. Siwek, PWN, Warszawa 1992.

Bailie J., Hume on Morality, London-New York 2000.

Berkeley G., Próba stworzenia nowej teorii widzenia, [w:] tenże, Próba stworzenia nowej teorii widzenia i inne eseje filozoficzne, przeł. A. Grzeliński i in., WN UMK, Toruń 2011.

Bricke J., Hume's Philosophy of Mind, Princeton 1980.

Costa M. J., Hume and Causal Realism, „Australasian Journal of Philosophy” 1989, vol. 67 , no. 2 .

Costelloe T. M., Hume, Kant, and the Antinomy of Taste, "Journal of the History of Philosophy" 2003, vol. 41, no. 2.

Davidson D., Hume's Cognitive Theory of Pride, „The Journal of Philosophy” 1976, vol. LXXIII, no. 4.

Deleuze G., Empiryzm i subiektywność. Esej o naturze ludzkiej według Hume’a, przeł. K. Jarosz, Warszawa 2000.

Flew A., Hume's Philosophy of Belief. A Study of His First Inquiry, New York 1961.

Friday J., Hume's Sceptical Standard of Taste, „Journal of the History of Philosophy” 1998, vol. 36, no. 4.

Glathe A., Hume's Theory of the Passions and of Morals, Berkeley-Los Angeles 1950.

Grzeliński A., Angielski spór o istotę piękna. Koncepcje estetyczne Shaftesbury'ego i Burke’a, Toruń 2001.

Grzeliński A., Człowiek $i$ duch nieskończony. Immaterializm George’a Berkeleya, WN UMK, Toruń 2010.

Grzeliński A., Kategorie „podmiotu” i „przedmiotu” w Dawida Hume’ a nauce o naturze ludzkiej, Wydawnictwo UMK, Toruń 2005. 
Hume D., Badania dotyczace rozumu ludzkiego, przeł. J. Łukasiewicz i K. Twardowski, PWN, Warszawa 1977.

Hume D., Rozprawa o uczuciach, przeł. A. Grzeliński, „Filo-Sofija” 2009, nr 1 (8), s. 267.

Hume D., Sceptyk, [w:] Eseje z dziedziny moralności i literatury, przeł. T. Tatarkiewiczowa, PWN, Warszawa 1955.

Hume D., Sprawdzian smaku, [w:] Eseje z dziedziny moralności i literatury, przeł. T. Tatarkiewiczowa, PWN, Warszawa 1955.

Hume D., Traktat o naturze ludzkiej, przeł. Cz. Znamierowski, Aletheia, Warszawa 2005.

Hutcheson F., An Essay on the Nature and Conduct of the Passions and Affections, with Illustrations on the Moral Sense (1742), ed. A. Garrett, Liberty Fund, Indianapolis 2002.

Jedynak S., Hume, Warszawa 1974.

Kearns Th. K., “General Rules” in Hume's Treatise, „Journal of the History of Philosophy” 1970 , no. 8.

Kopania J., Funkcje poznawcze Descartes'a teorii idei, Dział Wydawnictw Filii UW w Białymstoku, Białystok 1988.

Locke J., Myśli o wychowaniu, przeł. F. Wnorowski, Ossolineum, Wrocław-Kraków 1959.

Locke J., Rozważania dotyczace rozumu ludzkiego, przeł. B. J. Gawecki, PWN, Kraków 1955.

Morawski S., O podstawowych zagadnieniach estetyki angielskiej XVIII w., [w:] Studia $z$ historii myśli estetycznej XVIII i XIX w., Warszawa 1961.

Ossowska M., Dawid Hume jako obserwator i kodyfikator moralności, [w:] Myśl moralna oświecenia angielskiego, Warszawa 1966.

Pyka M., O uczuciach, wartościach i sympatii. David Hume, Max Scheler, Univeristas, Kraków 1999.

Rorty Amelié O., 'Pride Produces the Idea of Self': Hume on Moral Agency, „Australasian Journal of Philosophy" 1990, vol. 68, no. 3.

Rutkowski M., Krytyka oceny moralnej w etyce Davida Hume’a, „Studia Filozoficzne” 1990, nr 1.

Rutkowski M., Rola rozumu w decyzjach moralnych. Etyka Davida Hume’a, Warszawa 2001.

Rutkowski M., Teoria „bezstronnego obserwatora” w etyce Dawida Hume’a, „Studia Filozoficzne" 1989, nr 5.

Savile A., Hume, Kant and the Standard of Taste, [w:] Kantian Aesthetics Pursued, Edinburgh 1993.

Shaftesbury, An Inquiry Concerning Virtue, or Merit (1699), [w:] Characteristics of Men, Manners, Opinions, and Times, ed. D. Den Uyl, Indianapolis 2001. 
Shaftesbury, Moraliści, [w:] tenże, List o entuzjazmie. Moraliści, przeł. A. Grzeliński, WN UMK, Torun 2007.

Szewczyk J., Krytyka teorii przyczynowości Dawida Hume’a, Kraków 1980.

Tulejski T., Konserwatyzm bez Boga. Dawida Hume’a wizja społeczeństwa, państwa i prawa, Fijorr Publishing, Chicago-Warszawa 2009.

Wawrzonkowski K., Teoria estetyczna w Hume 'owskiej nauce o naturze ludzkiej, „Filo-Sofija" 2006, nr 1(6), ss. 207-222.

Wawrzonkowski K., Wyobraźnia i wzniosłość. Teoriopoznawcze podstawy wybranych brytyjskich koncepcji estetycznych XVIII wieku, Wydawnictwo TAKO, Toruń 2010.

Wieand, Hume's Two Standards of Taste, „Philosophical Quarterly” 1997, vol. 47, no. 1.

Yolton J. W., The Concept of Experience in Locke and Hume, „Journal of the History of Philosophy" 2002, vol. 40, no. 1.

Zabieglik S., Z filozofii szkockiego oświecenia, Gdańsk 1997.

\begin{abstract}
The Role of Imagination in Hume's Science of Human Nature. From Epistemology to Ethics and Aesthetics
\end{abstract}

The aim of the article is to present the role of associations in Hume's science of human nature. I analyse this issue with reference to his epistemological, ethical and aesthetical deliberations. Hume was the first thinker who made so wide use of associations in his description of the most important spheres of human activities, and, as we find in all his philosophical writings, was convinced that it was his greatest achievement. Referring to the ways in which imagination joins ideas, Hume was able to explain its mechanisms as a part of his model of human nature.

Key words: Hume, epistemology, ethics, aesthetics, ideas, principles of association, relations of ideas, imagination, taste 